Jelena Krstić1

Milica Kostić-Stanković ${ }^{2}$

Jelena Cvijović ${ }^{3}$
JEL: M37, Q59

DOI: 10.5937/industrija49-31692

UDC: leave blank

Review Paper

\title{
Green advertising and its impact on environmentally friendly consumption choices - A review
}

\author{
Article history: \\ Received: 5 January 2021 \\ Sent for revision: 20 February 2021 \\ Received in revised form: 2 April 2021 \\ Accepted: 10 April 2021 \\ Available online: 30 April 2021
}

\begin{abstract}
Research on various environmental topics, among which is the topic of green advertising, has been growing during last three decades, but it is yet to gain its full potential. Since the topic of green advertising has been gaining rising attention of scholars, the body of knowledge on this topic has been growing as well. Green advertising in general aims to promote products produced in an environmentally-friendly manner, or to promote advertiser's corporate responsibility toward an environment. The evaluation of green advertising effectiveness is necessary in order to stimulate cognitive and affective reactions of consumers to green advertisements, as well as their subsequent environmentally friendly behaviour. This article contains the review of the relevant literature on the topic of green advertising effectiveness. The findings of the literature review indicate that green advertising represents an effective communication means to influence consumers' attitudes and behaviour, even though its effectiveness is often mediated by certain factors,
\end{abstract}

\footnotetext{
${ }^{1}$ Economics Institute

2 University of Belgrade, Faculty of Organizational Sciences

${ }^{3}$ University of Belgrade, Faculty of Organizational Sciences, vuksanovicjelena1@gmail.com
} 
like: consumers' environmental consciousness, consumers' regulatory focus, consumers' scepticism, claim type.

Keywords: Green advertising, Effectiveness, Consumer attitudes, Environmentally friendly behaviour

\section{Zeleno oglašavanje i njegov uticaj na ekološki prihvatljive potrošačke izbore - Pregled literature}

Apstrakt: Istraživanje u oblasti različitih ekoloških tema, među kojima je i tema zelenog oglašavanja, dobija sve veći značaj tokom poslednje tri decenije, iako bi tek trebalo da dostigne svoj puni potencijal. Kako koncept zelenog oglašavanja privlači sve veću pažnju naučnika, uporedo raste i znanje o ovoj temi. Zeleno oglašavanje, generalno, ima za cilj promociju proizvoda proizvedenih na ekološki prihvatljiv način ili promovisanje korporativne odgovornosti oglašavača prema životnoj sredini. Procena efektivnosti zelenog oglašavanja je neophodna kako bi se podstakle kognitivne i afektivne reakcije potrošača na ove oglasne poruke, kao i njihovo naknadno ekološko ponašanje. Ovaj rad sadrži pregled relevantne literature na temu efektivnosti zelenog oglašavanja. Rezultati analize literature pokazuju da zeleno oglašavanje predstavlja efikasno sredstvo komunikacije u kontekstu uticaja na stavove $i$ ponašanje potrošača, iako je ostvarena efektivnost često posredovana dejstvom određenih faktora, kao što su: svest potrošača o životnoj sredini, regulatorni fokus potrošača, skepticizam potrošača, tip oglasne poruke.

Ključne reči: Zeleno oglašavanje, efektivnost, stavovi potrošača, ekološki prihvatljivo ponašanje.

\section{Introduction}

In modern social and market conditions, environmental awareness represents a significant issue in consumer behaviour (Tucker, Rifon, Lee, \& Reece, 2012; Royne, Martinez, Oakley, \& Fox, 2012; Pagiaslis \& Krontalis, 2014; Kitić, Kostić-Stanković, Cvijović, \& Lečić-Cvetković, 2015) and green marketing communications represent an increasing trend (Alamsyah, Othman, \& Mohammed, 2020). Environmental knowledge of consumers, which includes their awareness and information about the environment and ecological consequences of different actions, has improved (Pagiaslis \& Krontalis, 2014). For organizations, it has become very significant to establish their reputation of being environmentally responsible, so "green" communication strategies and activities are created to foster such perception that an organization is dedicated to sustainability and stimulating consumers' environmentally friendly behaviour 94 
(Joshi \& Kronrod, 2020). Green marketing is based on the assumption that consumers will observe green features of products as an advantage, so they will develop positive attitudes and make purchasing decisions for green products instead of regular, non-green product (Bukhari, 2011). While majority of authors consider that environmentally conscious consumers are willing to put greater involvement into decision making when purchasing green products, it may also be the case that the availability of a "green" version of products seems to enable "green" consumers to deploy "a new heuristic" that enables them to make simple decisions with less effort and time (Thøgersen, Jørgensen, \& Sandager, 2012).

However, in the literature, the so called "green gap" was determined as the difference between consumers' intentions to behave environmentally and actual behaviour (Fowler \& Close, 2012). Therefore, the examination of advertising effectiveness and factors that influence the obtained effects is necessary in order to stimulate cognitive and affective reactions to green advertisements, as well as subsequent conative reactions.

\section{The concept of green advertising in marketing literature}

Advertising through various media has a major role in communication and creation of awareness about environmental topics in general public and encourages demand for green products in the market (Grillo, Tokarczyk, \& Hansen, 2008). This type of advertising is often referred to as green advertising and it represents communication about products produced in an environmentally-friendly manner (made from recycled and recyclable components or manufactured in a more energy efficiently manner) or communication about organization's general commitment to sustainability of certain brands (Reich \& Armstrong Soule, 2016). Fowler and Close (2012) defined green advertising as a type of advertising that "explicitly or implicitly promotes an awareness of environmental issues and/or suggests behaviours useful in minimizing or correcting these environmental issues". Green advertisement represents efficient means to "influence consumers' purchasing behaviour that will strongly encourage consumers to buy products that are ecofriendly to our environment" (Yeng \& Yazdanifard, 2015). With green advertising, organizations try to develop an image of environmental friendliness, both at corporate and product level, and make an influence on purchase decisions of customers (Yazdanifard \& Mercy, 2011; Jayaram, Manrai, \& Manrai, 2015). Green advertising is also defined as "advertising that claims the advertised products are environmentally friendly or that their production process conserves resources or energy" (Chang, 2011). Pranee 
(2010) states that the goal of green advertising is to provide information to consumers about environmental utilities of organizations' products/services. According to Atkinson and Rosenthal (2014), in order to be categorized as green, advertising have to contain "the inclusion of environmentally friendly features and attributes as a persuasive selling point".

There are different variations of green advertisements, depending on the appeals, claims or frames that are used for conveying the green message. The most common typology is on green and non-green appeals, as it is a recommendable approach in the literature (Hartmann, Apaolaza, \& Eisend 2016; White, MacDonnell, \& Dahl, 2011). It is considered that green advertising contains a broad variety of forms, "from simple environmental-friendly claims of products, to corporate images emphasizing environmental credentials, to public events promoting environmental responsibilities" (Hartmann \& ApaolazaIbáñez, 2009). According to Green and Peloza (2014), two forms of advertising appeals are the most common: appeals based on consumer benefits (e.g., cost savings) and appeals based on societal benefits (e.g., reduced emissions). Communication strategies that emphasize different benefits are also noted in Green \& Peloza (2014) and Kareklas, Carlson, \& Muehling (2012). Previous research indicates that consumers, when purchasing environmentally oriented products, place personal benefits aside (e.g., Peattie \& Crane, 2005; Griskevicius, Van den Bergh, \& Tybur, 2010), therefore, it is expected that ecological-benefit appeal would be considered more important for more environmentally conscious consumers (Tucker et al., 2012; Ku, Kuo, Wu, \& Wu, 2012). Chang, Zhang and Xie (2015) stated that messages in green advertising can be framed in two ways - as "gain frame" (positive aspects of purchasing/consuming a product or behaving certain way) or "loss frame" (negative consequences of not purchasing/consuming a product or behaving certain way). Tiwari, Tripath and Srivastava (2011) pointed out that there are three categories of green advertising - ads related to the environment, ads related to green lifestyle, and corporate ads related to environmental responsibility. Furthermore, Leonidou, Leonidou, Palihawadana, \& Hultman (2011) classified green ads as "product-oriented, process-oriented, imageoriented and environmental fact oriented".

Banerjee, Gulas and lyer (1995) noted that green ads can be observed according to three dimensions: sponsor (for-profit or non-profit), focus (on the organization/product or consumer) and depth based on the complexity of environmental information they provide (shallow, moderate or deep). According to Fowler and Close (2012), there are: advertisers on macro-level (conveying broad "save-the-planet" messages like), advertisers on meso-level (advertising an environmental product or service that can contribute to decreasing of certain concerns), and micro-level (based on stimulating conscientious consumption at the local level).

96

Industrija, Vol.49, No.1, 2021 
During past decades, the intensity of the research on various environmental issues has been following the rise of public concern on such issues (Cleveland, Kalamas, \& Laroche, 2012). The importance of the issue rose during 90 s when its effectiveness started to be analysed (e.g., Carlson, Grove, \& Kangun, 1993; Zinkhan \& Carlson, 1995; Banerjee et al., 1995; Kilbourne, 1995; Shrum, McCarty, \& Lowrey, 1995), but it is yet to gain it full potential. The topic of green advertising has been gaining significant attention of scholars over the years, so the body of knowledge on this topic has been growing as well (Taylor, 2014). The main results of the growing research in this area are greater theoretical richness, building of complex models, and greater practical implications (Sheehan \& Atkinson, 2012).

\section{3. The effectiveness of green advertising}

One of the areas that is especially important when it comes to green advertising, is the examination of consumers' responses to environmentally oriented advertising appeals, or the effectiveness of such advertisements. For advertisers, it is very challenging to develop the most effective way to communicate product's environmental friendliness, due to the complexity of this issue. Because of that, many researchers in this area focussed on the examination of the effectiveness of green advertisements, with the goal to provide empirical evidence and give practical recommendations to advertisers how to successfully communicate green messages and enhance perceptions of their corporate or product's environmental friendliness.

This article contains the review of the relevant literature on the topic of green advertising effectiveness. The review of selected studies on green advertising effectiveness is given in Table 1.

The concept of involvement is often taken into consideration. One of the earlier researches examined consumers' response to "green" and "non-green" print advertisements, mediated with consumers' environmental involvement. The results indicated that, in case of highly involved consumers, these two types of advertisement demonstrated no significant differences in effects, while, in case of less involved consumers, the persuasiveness of green appeal was higher (Schuhwerk \& Lefkoff-Hagius, 1995). The research of D'Souza and Taghian (2005) aimed to compare cognitive and affective responses towards advertisements of high and low involvement consumers. The results indicate that customers that are lower involved demonstrate a stronger disregard for green advertising regarding both categories of responses. 
Table 1. The review of academic literature on the topic of green advertising effectiveness (1)

\begin{tabular}{|c|c|c|}
\hline Author(s) and year & Research area & Major findings \\
\hline $\begin{array}{l}\text { Schuhwerk \& } \\
\text { Lefkoff-Hagius } \\
(1995)\end{array}$ & $\begin{array}{l}\text { Consumers' reaction to green/non- } \\
\text { green appeal print ads }\end{array}$ & $\begin{array}{c}\text { Green appeal significantly more } \\
\text { persuasive for less environmentally } \\
\text { involved consumers }\end{array}$ \\
\hline Chan (2000) & $\begin{array}{c}\text { The impact of environmental claim } \\
\text { type and the green image of source } \\
\text { country }\end{array}$ & $\begin{array}{l}\text { Both factors significantly affect the } \\
\text { effectiveness }\end{array}$ \\
\hline $\begin{array}{l}\text { D’Souza \& } \\
\text { Taghian (2005) }\end{array}$ & $\begin{array}{l}\text { Differences in attitudes of high/low } \\
\text { involved consumers }\end{array}$ & $\begin{array}{c}\text { Stronger disregard of low involved } \\
\text { customers }\end{array}$ \\
\hline $\begin{array}{l}\text { Hartmann \& } \\
\text { Apaolaza-lbáñez } \\
(2009)\end{array}$ & $\begin{array}{c}\text { Whether brand association with } \\
\text { nature imagery improves } \\
\text { effectiveness }\end{array}$ & $\begin{array}{l}\text { The associations with nature affect } \\
\text { consumer's attitudes in positive way }\end{array}$ \\
\hline Chang (2011) & $\begin{array}{c}\text { Claims that lead to consumers' } \\
\text { ambivalent attitudes }\end{array}$ & $\begin{array}{l}\text { High-effort claims lead to decreased } \\
\text { believability of the ad }\end{array}$ \\
\hline Chang (2012) & $\begin{array}{l}\text { The effects of guilt appeals and } \\
\text { moderating roles of issue proximity }\end{array}$ & $\begin{array}{l}\text { Guilt appeals are equally effective as } \\
\text { non-guilt appeals in case of low-proximity }\end{array}$ \\
\hline $\begin{array}{l}\text { Bickart \& Ruth } \\
\text { (2012) }\end{array}$ & $\begin{array}{l}\text { Conditions that affect the } \\
\text { persuasiveness of eco-seals }\end{array}$ & $\begin{array}{l}\text { Persuasiveness of eco-seals depend on } \\
\text { brand familiarity, source and appeal }\end{array}$ \\
\hline Ku et al. (2012) & $\begin{array}{c}\text { The impact of self-regulatory focus } \\
\text { on reaction to green/nongreen } \\
\text { appeals }\end{array}$ & $\begin{array}{l}\text { Prevention-focused consumers more } \\
\text { persuaded when appeals emphasize } \\
\text { green product attributes }\end{array}$ \\
\hline $\begin{array}{l}\text { Kareklas et al. } \\
(2012)\end{array}$ & $\begin{array}{c}\text { The effectiveness of message } \\
\text { frames in the context of an } \\
\text { environmentally focused advertising } \\
\text { campaign }\end{array}$ & $\begin{array}{l}\text { Prevention- focused appeals led to more } \\
\text { favourable attitudes of individuals in } \\
\text { independent self-view }\end{array}$ \\
\hline $\begin{array}{l}\text { Royne et al. } \\
(2012)\end{array}$ & $\begin{array}{l}\text { The effectiveness of environmental/ } \\
\text { personal benefit appeals and } .99 / .00 \\
\text { price endings }\end{array}$ & $\begin{array}{c}\text { An environmental appeal and a .00 price } \\
\text { ending led to the perceptions of highest } \\
\text { quality }\end{array}$ \\
\hline $\begin{array}{l}\text { Alniacik \& Yilmaz } \\
(2012)\end{array}$ & $\begin{array}{l}\text { How green claim and product's } \\
\text { environmental relevance influence } \\
\text { advertising effectiveness }\end{array}$ & $\begin{array}{l}\text { Green claims ameliorate the ad } \\
\text { effectiveness of low environmental } \\
\text { relevance products }\end{array}$ \\
\hline $\begin{array}{l}\text { Xie \& Kronrad, } \\
(2012)\end{array}$ & $\begin{array}{l}\text { Do numerical precision signals } \\
\text { influence sceptical consumers }\end{array}$ & $\begin{array}{l}\text { Highly sceptical consumers are less } \\
\text { responsive to numerical precision }\end{array}$ \\
\hline $\begin{array}{l}\text { Tucker et al. } \\
\text { (2012) }\end{array}$ & $\begin{array}{l}\text { The role of consumer characteristics } \\
\text { in receptiveness to ad claims }\end{array}$ & $\begin{array}{c}\text { Participants with "positive attitudes } \\
\text { toward environmental protection are } \\
\text { equally receptive to all claims" }\end{array}$ \\
\hline $\begin{array}{l}\text { Hartmann \& } \\
\text { Apaolaza-lbánnez } \\
(2013)\end{array}$ & $\begin{array}{l}\text { The influences of consumers' natural } \\
\text { environments on affective reactions }\end{array}$ & $\begin{array}{l}\text { Recommended global strategy that } \\
\text { includes standardised use of landscapes } \\
\text { in advertisements }\end{array}$ \\
\hline $\begin{array}{l}\text { Hartmann et al. } \\
(2014)\end{array}$ & $\begin{array}{c}\text { The behavioural effects of cognitive } \\
\text { threat appraisal and emotional fear } \\
\text { response in threat appeals }\end{array}$ & $\begin{array}{l}\text { Both were found to significantly enhance } \\
\text { pro-environmental intentions }\end{array}$ \\
\hline $\begin{array}{l}\text { Atkinson \& } \\
\text { Rosenthal, (2014) }\end{array}$ & $\begin{array}{l}\text { Aspects of eco-label design which } \\
\text { lead to better effects }\end{array}$ & $\begin{array}{l}\text { Eco-labels influence product and label } \\
\text { source attitudes and trust in the label }\end{array}$ \\
\hline $\begin{array}{l}\text { Green \& Peloza, } \\
(2014)\end{array}$ & $\begin{array}{l}\text { The impact of appeals and } \\
\text { consumption contexts }\end{array}$ & $\begin{array}{l}\text { Consumers better react to other benefit } \\
\text { appeals in contexts with public } \\
\text { accountability }\end{array}$ \\
\hline
\end{tabular}

Source: Authors

98

Industrija, Vol.49, No.1, 2021 
Table 1. The review of academic literature on the topic of green advertising effectiveness (2)

\begin{tabular}{|c|c|c|}
\hline $\begin{array}{l}\text { Author(s) and } \\
\text { year }\end{array}$ & Research area & Main findings \\
\hline $\begin{array}{c}\text { Mathes\& } \\
\text { Wonneberger } \\
(2014)\end{array}$ & $\begin{array}{l}\text { Do green consumers have tendency not } \\
\text { to trust green advertising }\end{array}$ & $\begin{array}{l}\text { Green consumers perceive greater } \\
\text { informational utility of green ads which } \\
\text { decreases their scepticism }\end{array}$ \\
\hline $\begin{array}{l}\text { Chang et al. } \\
\qquad(2015)\end{array}$ & $\begin{array}{l}\text { The impact of gain/loss framed messages } \\
\text { on attitudes and purchase intentions }\end{array}$ & $\begin{array}{l}\text { A congruency between gain/loss frame } \\
\text { and high/low level construal leads to } \\
\text { better attitudes and purchase intention }\end{array}$ \\
\hline $\begin{array}{l}\text { Parguel et. } \\
(2015)\end{array}$ & $\begin{array}{c}\text { Whether 'executional greenwashing' } \\
\text { shapes consumers' evaluation }\end{array}$ & $\begin{array}{l}\text { It leads to consumers' perception of } \\
\text { ecological image of a brand }\end{array}$ \\
\hline $\begin{array}{l}\text { Yoon et al. } \\
(2016)\end{array}$ & $\begin{array}{l}\text { Comparing American and Korean } \\
\text { reactions to green advertising }\end{array}$ & $\begin{array}{l}\text { Efforts that consumers put into making } \\
\text { prior environmental pledges influence } \\
\text { effectiveness }\end{array}$ \\
\hline $\begin{array}{l}\text { Bhatnagar \& } \\
\text { McKay-Nesbitt } \\
(2016)\end{array}$ & $\begin{array}{l}\text { The impact of consumers' regulatory } \\
\text { focus (promotion/prevention) on } \\
\text { environmentally responsible reactions }\end{array}$ & $\begin{array}{l}\text { Promotion focus is related with } \\
\text { environmental concern and favourable } \\
\text { attitudes towards advertising }\end{array}$ \\
\hline $\begin{array}{c}\text { Reich \& } \\
\text { Armstrong } \\
\text { Soule (2016) } \\
\end{array}$ & $\begin{array}{c}\text { Comparison of consumer response to } \\
\text { traditional appeals and "green } \\
\text { demarketing" (GD) appeals }\end{array}$ & $\begin{array}{c}\text { Consumers' attitudes toward traditional } \\
\text { green ads are more favourable than } \\
\text { those for GD ads }\end{array}$ \\
\hline $\begin{array}{l}\text { Chen \& Chiu, } \\
\quad(2016)\end{array}$ & $\begin{array}{l}\text { The influence of green messages on } \\
\text { perceived effectiveness of green products }\end{array}$ & $\begin{array}{l}\text { Better perceptions of a green product's } \\
\text { effectiveness of environmentally } \\
\text { conscious consumers }\end{array}$ \\
\hline $\begin{array}{l}\text { Shin et al. } \\
2017\end{array}$ & $\begin{array}{c}\text { The effectiveness of fear appeal in green } \\
\text { advertising }\end{array}$ & $\begin{array}{l}\text { A fear appeal negatively affected } \\
\text { attitudes toward the ad and product }\end{array}$ \\
\hline $\begin{array}{l}\text { Muralidharan } \\
\text { et al. (2017) }\end{array}$ & $\begin{array}{l}\text { The effectiveness of culturally congruent } \\
\text { appeals }\end{array}$ & $\begin{array}{c}\text { Collectivistic appeals more effective for } \\
\text { Indian individualistic for American } \\
\text { consumers }\end{array}$ \\
\hline $\begin{array}{l}\text { Kim et al., } \\
\text { (2017) }\end{array}$ & $\begin{array}{l}\text { The role of cultural differences in showing } \\
\text { reactance to assertive advertising }\end{array}$ & $\begin{array}{l}\text { Non-assertive messages more } \\
\text { persuasive for American/both equally } \\
\text { for South Korean consumers }\end{array}$ \\
\hline $\begin{array}{l}\text { Ryoo et al. } \\
\quad(2017)\end{array}$ & $\begin{array}{c}\text { The effect of two types of descriptive } \\
\text { norms on sustainable behaviour of } \\
\text { consumers }\end{array}$ & $\begin{array}{c}\text { The congruence between types of } \\
\text { descriptive norms and construal level } \\
\text { messages leads to changes }\end{array}$ \\
\hline $\begin{array}{l}\text { Mo et al. } \\
(2018)\end{array}$ & $\begin{array}{c}\text { The effectiveness of functional green } \\
\text { advertising }\end{array}$ & $\begin{array}{l}\text { Perceived stronger impact on others' } \\
\text { purchase decisions than on } \\
\text { respondents' own decisions }\end{array}$ \\
\hline $\begin{array}{l}\text { Bailey et al. } \\
\text { (2018) }\end{array}$ & $\begin{array}{l}\text { The impact of consumers' GREEN } \\
\text { consumption values }\end{array}$ & $\begin{array}{l}\text { GREEN consumption values explain } \\
\text { reactions to advertising }\end{array}$ \\
\hline $\begin{array}{l}\text { Schmuck et al. } \\
(2018)\end{array}$ & $\begin{array}{l}\text { How greenwashing affects perception of } \\
\text { ads and brands }\end{array}$ & $\begin{array}{l}\text { Vague claims do not intensify perceived } \\
\text { greenwashing while false claims do }\end{array}$ \\
\hline $\begin{array}{l}\text { Meijers et al. } \\
(2019)\end{array}$ & $\begin{array}{l}\text { Effects after consumers have purchased } \\
\text { an advertised 'green' product }\end{array}$ & $\begin{array}{c}\text { Possible paradoxical post-purchase } \\
\text { effects }\end{array}$ \\
\hline $\begin{array}{l}\text { Sahin et al. } \\
\text { (2019) }\end{array}$ & $\begin{array}{l}\text { The effects of green advertising images } \\
\text { on consumer behaviour }\end{array}$ & $\begin{array}{c}\text { Green text, green certification logo, and } \\
\text { green combination ads more effective } \\
\text { than non-green ads }\end{array}$ \\
\hline $\begin{array}{l}\text { Ursey et al. } \\
\qquad(2020)\end{array}$ & $\begin{array}{c}\text { The impact of advertising appeal and } \\
\text { perceptions of typicality of a green } \\
\text { product }\end{array}$ & $\begin{array}{l}\text { The impact of congruity between the } \\
\text { used appeal and previously held } \\
\text { product category assumptions }\end{array}$ \\
\hline $\begin{array}{l}\text { Alamsyah et al. } \\
2020\end{array}$ & $\begin{array}{l}\text { The correlation between green } \\
\text { advertising, green brand image and } \\
\text { green awareness of customers }\end{array}$ & $\begin{array}{c}\text { Green advertising can improve } \\
\text { customers' green awareness and } \\
\text { purchasing intentions }\end{array}$ \\
\hline
\end{tabular}

Source: Authors

Industrija, Vol.49, No.1, 2021 
The effectiveness of certain appeals was also examined in literature. Shin, Ki and Griffin (2017) examined the effectiveness of usage of fear appeals, which are used to arouse an impression of threat and discovered that it affected attitude towards the ad and product in a negative sense. On the other hand, Hartmann et al. (2014) examined the effectiveness of threat appeals in green advertising and find out that exposure to such advertisements leads to increased cognitive level of perceived threat, which further stimulate consumers' intention to participate in promoted environmentally oriented behaviour. Chang (2012) examined the effectiveness of guilt appeals used in green advertising, by considering "moderating roles of issue proximity and environmental consciousness", and found out that these appeals have no more significant effects than other appeals in case when low-proximity issue is promoted to consumers with low level of environmental consciousness, but have an adverse effect in case of presenting promoting a high-proximity issue to consumers who are more environmentally conscious. Green and Peloza (2014) examined the effects of two forms of environmentally friendly advertising appeals - one that emphasizes self-benefits (e.g. cost savings) and other that emphasizes societal benefits (e.g. lower emissions) depending on the consumption contexts. Authors find out that, in public contexts, consumers demonstrate higher responsiveness to societal benefit appeals, while in settings considered more private, they demonstrate higher responsiveness to self-benefit appeals. Kareklas et al. (2012) examined the effectiveness of prevention and promotion focused environmental appeals depending on the consumers' perspective - self-perspective or others-perspective and found out that prevention-focused appeals generated more favourable attitudes for consumers with independent self-view, while promotion-focused appeals generated same or better attitudes for consumers with others-perspective. Mo, Liu and Liu (2018) examined the effectiveness of functional green appeals, which are focused on promotion of the environmental advantages of a product, observed from the self and others perspective. Authors found out that, in consumers' opinion, functional ads influence purchase decisions of others more powerfully than they influence consumers' own purchase decisions and this is more prominent in case of consumers with high environmental concern. Ku et al. (2012) investigated consumers' responsiveness and purchase to green opposite to nongreen advertising appeals depending on whether they are more prevention or promotion. Findings show that consumers that are prevention focused are more intensely persuaded with green appeals, while the opposite situation occurred in case of promotion focused consumers. Similarly, Bhatnagar and McKay-Nesbitt (2016) examined the influence of consumers' promotion and prevention focuses on different environmentally responsible reactions and find out that promotion focus is more accompanied with environmental concern, favourable attitudes towards environmentally related 
advertising recommendations and intentions to behave in accordance with such recommends than is the case for consumers with prevention focus.

Reich and Armstrong Soule (2016) compared the effectiveness of traditional green advertising appeals to so-called "green demarketing" appeals, which promote reduced consumption as benefit for the environment. Traditional green ads appeared to be more effective when used for product advertising, while in case of institutional advertising, green demarketing appeals seemed to be more effective. The research of Usrey, Palihawadana, Saridakis and Theotokis (2020) focused on the situations when an implicit ad of green products has greater effects than explicit ads. Their findings indicate that implicit green communication "leads to higher performance evaluations for products that are less commonly green and for products that have an optional green mode". The findings of Segev, Fernandes and Hong (2016), who performed the content analysis on green print ads, indicate that environmental claims in print ads are often evaluated as acceptable and reliable.

This study of Sahin, Baloglu and Topcuoglu (2019) examined message factors that rise the effects of green advertising and found out that ads containing green text, green certification logo and green visual cues, appeared to generate better attitudes toward the advertisement and advertised brand than non-green ads. Hartmann and Apaolaza-lbáñez (2009) examined the effectiveness of ads containing pleasant nature scenery, as opposed to those containing informational claims (information on green features of the product). While both types of advertisements positively influenced consumers' brand attitudes, ads containing informational claims led to enhanced brand attitudes based on the brand associations related to environmental features. On the other hand, appeals of pleasant nature imagery led to specific emotional experiences similar to experiences that emerge in contact with nature.

Different message framing was the topic of some research. For example, Chang et al. (2015) examined the effectiveness of gain or loss framed messages, taking into account the moderating role of temporal distance. The findings demonstrate that, in case of loss-framed green messages, consumers demonstrate a more favourable ad and brand attitudes when the focus is put on the environmental changes in present time. On the other hand, gain-framed green ads lead to more favourable attitudes toward the ad and higher purchase intentions when advertised product focuses on future changes. In their study, Royne et al. (2012) examined consumers' perceptions of appeals for two green products containing environmental opposite to personal benefits and appeals containing .99 opposite to .00 price endings. They found out that the product advertised by using an environmental appeal and a .00 price ending generated consumers' perceptions of the highest-quality and highest price, while the product advertised by using personal benefit appeal and a .99 price ending was 
perceived a bit lower regarding quality and price. The effectiveness of advertising appeals containing environmentally-relevant numerical claims was found to depend on the level of consumers' advertising scepticism. With this regard, Xie and Kronrod (2012) found out that consumers demonstrating a low level of scepticism have a tendency to perceive the advertised organization as more competent when precise numbers are presented in the advertisement, while highly sceptical consumers are less prone to be influenced by numerical information in this context.

The strength of environmental claims appears to be relevant factor of advertising effectiveness. The results of the study conducted by Alniacik and Yilmaz (2012) indicate the better effectiveness of specific environmental claims in relation to vague claims in advertisements of products with low environmental relevance. The study of Tucker et al. (2012) was based on the comparison of the effectiveness of three types of claims - a strong green product claim, a weak product claim, and a cause-related appeal to donate to a nor-for-profit environmental advocacy group and concluded that consumers with high environmental consciousness are equally receptive to all green themed ads, regardless of claim type. Chen and Chiu (2016) explored the effectiveness of "abstract/concrete and distant/proximal messages" in green advertising and found out that environmentally conscious consumers are more responsive to abstract and distant temporal messages, while less environmentally conscious consumers do not demonstrate different reactions to different types of messages.

Also, advertising effectiveness also depends on environmental awareness. Observed in environmental area, it can be assumed that different reactions to green communication through various media might be generated due to different environmental awareness levels. The importance of green awareness was also taken into consideration. It was found out that the exposure to green advertising can help improving customers' green awareness, which further can lead to the improvement of purchasing intentions of environmentally friendly products (Alamsyah et al., 2020). Bailey, Mishra and Tiamiyu (2018) developed a GREEN scale for measuring consumers' green consumption values, and examining their impact on attitudes and intentions. Their findings indicate positive impact of consumers' green consumption values on perceived trustworthiness of a green brand and favourable responses to different forms of green marketing communications.

Cultural differences are also observed as a factor that shapes effectiveness of green advertising. The findings of Kim, Baek, Yoon, Oh and Choi (2017) that American consumers are less convinced by assertive ad messages, while consumers from South Korea are equally convinced by both, assertive and nonassertive green ads. By also comparing the reactions of American and Korean 
consumers to green ads, Yoon, Kim and Baek (2016) emphasised that the strength of demanded effort plays an important role, and found out that Americans demonstrate more favourable attitudes toward massages promoting recycling in comparison to advertising which requires putting higher efforts from them, while Korean consumers showed less-favourable attitudes. Muralidharan, La-Ferle and Sung (2017) examined the effectiveness of collectivistic and individualistic appeals in two cultural contexts and found better effectiveness of collectivistic appeals on Indian consumers, and better effectiveness of individualistic appeals for American consumers. Certain types of environmental claims were found to be equally effective globally. Such is the case with messages containing nature imagery, which, according to the study of Hartmann and Apaolaza-Ibáñez (2013) do not need adaptation to target audiences and should be use in a standardized way, due to universal perception of environmental aesthetics. On the other hand, Chan (2000) pointed out the necessity of adaptation of environmental claims to different contexts, depending on how target group perceive the eco-friendliness of the source country, or, in other words, country's green image. The findings of Ryoo, Hyun and Sung (2017) indicate the necessity for adaptation of advertising messages to target groups, since it was "found out that consumers were more likely to join a sustainability campaign when the advertising appeal was conveyed with provincial norms (behavioural descriptions of a reference group distal (proximal) to one's local setting and circumstances) rather than with general norms".

The impact of misleading advertisements, or green washing and consumer scepticism are subjects of some studies. Schmuck, Matthes and Naderer (2018) examined how greenwashing affects perception of green ads and brands by consumers. They found out that vague environmental claims are not perceived as greenwashing, and can even have a positive impact on attitudes, unlike false claims, which cause greenwashing perceptions, and deteriorate attitudes toward ads and brands. Mathes and Wonneberger (2014) revisited the generally believed notion that more environmentally conscious consumers are sceptical toward green advertising and concluded that such consumers perceive "more informational utility in green ads than nongreen consumers", which further led to decrease of advertising scepticism. Parguel, BenoitMoreaua and Russell (2015) based their research on the examination of the so-called "executional greenwashing" effect, meaning "the use of natureevoking elements in advertisements to artificially enhance a brand's ecological image". They found out that such advertisements have a misleading effect by generating perceptions of the ecological image of the brand and thus generate positive brand attitudes. Chang (2011) explored the effectiveness of green claims depending on the perceived levels of advertisers' efforts and found out that green claims associated with greater expended efforts decrease credibility 
of green claims among ambivalent consumers, which leads to less favourable product evaluations. The research of Coleman, Bahnan, Kelkar and Curry (2011) showed that consumers that are enthusiastic for environmental protection may actually avoid green products, since they believe that, by ignoring false claims provided in green advertising, they are doing better for environmental community.

Bickart and Ruth (2012) examined "the conditions under which eco-seals are more or less persuasive", and found out that it depends on the extent of consumers' environmental concern, familiarity with the brand, source of the eco-seal and used ad appeal. Atkinson and Rosenthal found out that eco-labels have an influence on product and label source attitudes, and trust in the label, even though having little influence on consumers' purchase intents.

Meijers, Noordewier, Verlegh, Willems and Smith (2019) examined the impact of advertised products post-purchase effects on further environmentally friendly behaviour. In case of consumers with weak environmental identity, "the paradoxical post purchase licensing effect" appears, meaning that they demonstrate weaker intentions to participate in subsequent environmental behaviour, while consumers with a strong environmental identity demonstrate a higher intention to continue behaving in a similar way.

\subsection{Scepticism toward green advertising}

One of the most discussed issues is green advertising effectiveness and real impact it accomplishes in relation to different target groups is advertising scepticism. The effectiveness is put into question mostly due to the appearance of consumers' scepticism. Many authors emphasized the concern whether green advertising is perceived to communicate a sincere environmental message since presentation of green messages has become difficult. As D'Souza and Thaglian (2005) pointed out, "Advertising terms such as recyclable, environmentally friendly, ozone safe, biodegradable have become popular in green advertisements and consumers are often exposed to such messages, while some of these messages are met with consumer resistance". This occurs due to general skepticism regarding advertising that has been confirmed in literature (e.g., Obermiller, Spangenberg, \& MacLachlan, 2005) and due to increased ecological knowledge and easier accessibility to information through Internet. Few researches registered consumers' scepticism on green ads (Coleman et al., 2011; Xie \& Kronrod; 2012; Bickart \& Ruth 2012; Fowler \& Close 2012; Atkinson \& Rosenthal 2014) and some even emphasized the skepticism of green consumers in particular (Chang 2011; Finisterra do Paço \& Reis, 2012). 
As regarding providing false green claims in advertising, the term "greenwashing," was coined to define any ambiguous, misleading, false or inaccurate information disseminated by an advertiser in order to create environmentally responsible corporate or product image in public (Mitchell \& Ramey, 2011; Xie \& Kronrod, 2012; Parguel et al., 2015; Fernandes, Sagev, \& Leopold, 2020). As a result, consumers found it often difficult to make a distinction between genuine and deceptive environmental claims, which makes them sceptical of green advertising in general. The trust in green ads depends significantly on consumers' perception of motives of certain brand which disseminates the environmentally friendly message. In case of distrust, consumers are less probable to purchase advertised products or develop positive attitudes toward them (Thøgersen, 2002). Majority of research found out that, in general, more environmentally concerned consumers are more sceptical toward green claims presented in advertising (Finisterra do Paço \& Reis, 2012; Xie \& Kronrod, 2012). On the other hand, Matthes and Wonneberger (2014) opposed the statement of scepticism as highly misleading and without enough empirical evidence, and argued that environmentally conscious consumers actually trust green ads even more and that their perception of informational utility in green ads decrease their green advertising scepticism. They state that this confusion often occurs due to existence of general ad scepticism, which does not necessary coincide.

\section{Conclusion}

Green advertising is an important theoretical and practical concept of modern advertising, taking into account the importance that environmental responsibility of organizations and environmental behaviour of consumers have in modern market conditions. In order to formulate the most effective strategies of green advertising in practice, the theoretical study of this area focuses significantly on the effectiveness of green advertising, i.e., the impact it accomplishes on consumers' cognitive, affective and behavioural reactions. By giving a comprehensive overview of relevant articles on the topic of the effectiveness of green advertising, this paper provides a contribution to the coverage of the existing body of a literature. Based on the findings, it is concluded that there are significant empirical findings regarding green advertising effectiveness in the context of making an influence on consumers' attitudes towards ads and advertised products and brands and consequent behaviour. The effectiveness is found to be mediated by a large number of factors, including those that are advertisement-related such as claim type, advertising appeal and message elements, as well as those that are consumerrelated, such as: environmental consciousness, previous pro-environmental behaviour, personal characteristics, scepticism towards advertising, cultural 
differences etc. Also, it can be concluded that, despite the obvious research progress, this area still has a lot of issues to be examined and a great space for further empirical and practical contributions.

\section{References}

Alamsyah, D.P., Othman, N.A. \& Mohammed, H.A.A. (2020). The awareness of environmentally friendly products: The impact of green advertising and green brand image. Management Science Letters, 10(9), 1961-1968. doi: 10.5267/j.msl.2020.2.017

Alniacik, U. \& Yilmaz, C. (2012). The effectiveness of green advertising: influences of claim specificity, product's environmental relevance and consumers' proenvironmental orientation. Amfiteatru Economic. 14(31), 207-222

Atkinson, L., \& Rosenthal, S. (2014). Signaling the green sell: The influence of eco-label source, argument specificity, and product involvement on consumer trust. Journal of Advertising, 43(1), 33-45. doi: 10.1080/00913367.2013.834803

Bailey, A.A., Mishra, A.S., \& Tiamiyu, M.F. (2018). Application of GREEN scale to understanding US consumer response to green marketing communications. Psychology and Marketing, 35(11), 863-875, doi: 10.1002/mar.21140

Banerjee, S., Gulas, C.S. \& Iyer, E. (1995) Shades of green: a multidimensional analysis of environmental advertising. Journal of Advertising, 24(2), 21-32.

Banerjee, S., Gulas, C.S., \& lyer, E. (1995). Shades of Green: A Multidimensional Analysis of Environmental Advertising. Journal of Advertising. 24(2), 21-31.

Bhatnagar, N., \& McKay-Nesbitt, J. (2016) Pro-environment advertising messages: the role of regulatory focus. International Journal of Advertising. 35(1), 4-22, doi: 10.1080/02650487.2015.1101225

Bickart, B.A., \& Ruth, J.A. (2012). Green eco-seals and advertising persuasion. Journal of Advertising, 41(4), 51-67. doi: 10,2753/JOA0091-3367410404

Bukhari, S.S. (2011) Green Marketing and its impact on consumer behavior. European Journal of Business and Management, 3(4), 375-383

Carlson, L., Grove, S. J., \& Kangun, N. (1993). A content analysis of environmental advertising claims: A matrix method approach. Journal of Advertising, 22, 27-39.

Chan, R.Y.K. (2000). The effectiveness of environmental advertising: The role of claim type and the source country green image. International Journal of Advertising, 19(3), 349-375.

Chang, C. (2011). Feeling ambivalent about going green, implications for green advertising processing. Journal of Advertising, 40(4), 19-31. doi: $10.2307 / 23208833$

Chang, C-T. (2012). Are guilt appeals a panacea in green advertising? The right formula of issue proximity and environmental consciousness. International Journal of Advertising, 31(4), 741-771, doi: 10.2501/IJA-31-4-741-771

Chang, H., Zhang, L., \& Xie, G-X. (2015). Message framing in green advertising: the effect of construal level and consumer environmental concern. International Journal of Advertising, 34(1), 158-176. doi: 10.1080/02650487.2014.994731

106 
Chen, M-Y., \& Chiu, C-I. (2016). Go green: how to influence the perceived effectiveness of a green product? International Journal of Advertising. 35(4), 622-641, doi: 10.1080/02650487.2015.1105647

Cleveland, M., Kalamas, M., \& Laroche, M. (2012). It's Not Easy Being Green: Exploring Green Creeds, Green Deeds, and Environmental Locus of Control. Psychology and Marketing, 29(5), 293-305, doi: 10.1002/mar.20522

Coleman, L.J., Bahnan, N., Kelkar, M., \& Curry, N. (2011). Walking the walk: How the theory of reasoned action explains adult and student intentions to go green. Journal of Applied Business Research, 27(3),107-116.

D'Souza, C. and Taghian, M. (2005). Green advertising effects on attitude and choice of advertising themes. Asia Pacific Journal of Marketing and Logistics, 17(3), 5166.

Fernandes, J., Segev, S., \& Leopold, J. K. (2020). When consumers learn to spot deception in advertising: testing a literacy intervention to combat greenwashing. International Journal of Advertising, 39(7), 1115-1149, doi: 10.1080/02650487.2020.1765656

Finisterra do Paço, A.M., \& Reis, R. (2012). Factors affecting skepticism toward green advertising. Journal of Advertising, 41(4), 147-155, doi: 10.1080/00913367.2012.10672463

Fowler, A.R., \& Close, A.G. (2012). It ain't easy being green: Macro, meso, and micro green advertising agendas. Journal of Advertising, 41(4), 119-132. doi: 10.1080/00913367.2012.10672461

FuiYeng, W., \& Yazdanifard, R. (2015). Green Marketing: A Study of Consumers' Buying Behavior in Relation to Green Products. Global Journal of Management and Business Research, 15(5), 17-23.

Green, T., \& Peloza, J. (2014). Finding the right shade of green: The effect of advertising appeal type on environmentally friendly consumption. Journal of Advertising, 43(2), 128-141. doi: 10.1080/00913367.2013.834805

Grillo, N., Tokarczyk, J., \& Hansen, E. (2008). Green advertising developments in the U.S. forest sector: A follow-up. Forest Products Journal, 58(5), 40-46.

Griskevicius, V., Van den Bergh, B., \& Tybur, J.M. (2010). Going green to be seen: Status, reputation, and conspicuous conservation. Journal of Personality and Social Psychology, 98(3), 392-404. doi: 10.1037/a0017346

Hartmann, P., \& Apaolaza-lbáñez, V. (2009). Green advertising revisited. Conditioning virtual nature experiences. International Journal of Advertising, 28(4), 715-739. doi: 10.2501/S026.S048709200837

Hartmann, P., \& Apaolaza-lbáñez, V. (2013). Desert or rain. Standardisation of green advertising versus adaptation to the target audience's natural environment. European Journal of Marketing. 47(5/6), 917-933, doi 10.1108/03090561311308091

Hartmann, P., Apaolaza, V., \& Eisend, M. (2016). Nature imagery in non-green advertising: The effects of emotion, autobiographical memory, and consumer's green traits. Journal of Advertising, 45(4), 427-440. doi: 10.1080/00913367.2016.1190259

Jayaram, D., Manrai, A. K., \& Manrai, L. A. (2015). Effective use of marketing technology in Eastern Europe: Web analytics, social media, customer analytics, digital 
campaigns and mobile applications. Journal of Economics, Finance and Administrative Science, 20(39), 118-132. doi: 10.1016/j.jefas.2015.07.001

Joshi, P., \& Kronrod, A. (2020). Sounds of green: How brand name sounds metaphorically convey environmental friendliness. Journal of Advertising. 49(1), 61-77, doi.: 10.1080/00913367.2019.1696720

Kareklas, I., Carlson, J.R., \& Muehling, D.D. (2012). The role of regulatory focus and self-view in "green" advertising message framing. Journal of Advertising, 41(4), 25-39. doi: 10,2753/JOA0091-3367410402

Kilbourne, W.E. (1995) Green advertising: salvation or oxymoron. Journal of Advertising, 24(2), 7-19.

Kim, Y., Baek, T.H., Yoon, S., Oh, S., \& Choi, Y.K. (2017). Assertive Environmental Advertising and Reactance: Differences Between South Koreans and Americans. Journal of Advertising, 46(4), 550-564. doi: 10.1080/00913367.2017.1361878

Kitic, B., Kostic-Stankovic, M., Cvijovic, J., Lecic-Cvetkovic, D. (2015). Environmental Aspect of Business Communications. Management: Journal Of Sustainable Business And Management Solutions In Emerging Economies, 20(74), 69-76. doi: 10.7595/management.fon.2015.0004

$\mathrm{Ku}, \mathrm{H}-\mathrm{H} ., \mathrm{Kuo}, \mathrm{C}-\mathrm{C} ., \mathrm{Wu}, \mathrm{C}-\mathrm{L} .$, \& Wu, C-Y. (2012). Communicating green marketing appeals effectively: The role of consumers' motivational orientation to promotion versus prevention. Journal of Advertising, 41(4), 41-50. doi: 10,2753/JOA00913367410403

Leonidou, L. C., Leonidou, C. N., Palihawadana, D., \& Hultman, M. (2011). Evaluating the green advertising practices of international firms: a trend analysis. International Marketing Review, 28(1), 6-33. doi: 10.1108/02651331111107080

Matthes, J., \& Wonneberger, A. (2014). The skeptical green consumer revisited: Testing the relationship between green consumerism and skepticism toward advertising. Journal of Advertising, 43(2), 115-127, doi: 10.1080/00913367.2013.834804

Meijers, M.H.C., Noordewier, M.K., Verlegh, P.W.J., Willems, W., \& Smit, E.G. (2019) Paradoxical side effects of green advertising: how purchasing green products may instigate licensing effects for consumers with a weak environmental identity. International Journal of Advertising. 38(8), 1202-1223 doi: $10.1080 / 02650487.2019 .1607450$

Mitchell, L.D. \& Ramey, W.D. (2011). Look how green I am! An individual-level explanation for greenwashing. The Journal of Applied Business and Economics, 12(6), 40-45

Mo, Z., Liu, M.T., \& Liu, Y. (2018). Effects of functional green advertising on self and others. Psychology and Marketing. 35, 368-382, doi: 10.1002/mar.21092

Muralidharan, S., La Ferle, C., \& Sung, Y. (2017). Are we a product of our environment? Assessing culturally congruent Green advertising appeals, novelty, and environmental concern in India and the U.S.A. Asian Journal of Communication, 27(4), 396-414, doi:10.1080/01292986.2017.1280063

Obermiller, C., Spangenberg, E. and MacLachlan, D.L. (2005). Ad Skepticism: The Consequences of Disbelief. Journal of Advertising, 34(3), 7-17.

Pagiaslis, A., \& Krontalis, A.K. (2014) Green Consumption Behavior Antecedents: Environmental Concern, Knowledge, and Beliefs. Psychology and Marketing, 31(5), 335-348. doi: 10.1002/mar.20698 
Parguel, B., Benoit-Moreau, F., \& Russell, C.A. (2015). Can evoking nature in advertising mislead consumers? The power of 'executional greenwashing'. 34(1), 107-134, doi: 10.1080/02650487.2014.996116

Peattie, K., \& Crane, A. (2005). Green marketing: Legend, myth, farce, or prophesy? Qualitative Market Research: An International Journal, 8(4), 357-370. doi: $10.1108 / 13522750510619733$

Pranee, C. (2010). Marketing Ethical Implication and Social Responsibility. International Journal of Organizational Innovation, 2(3), 6-21

Reich, B.J., \& Armstrong Soule, C.A. (2016). Green demarketing in advertisements: Comparing "Buy green" and "Buy less" appeals in product and institutional advertising contexts. Journal of Advertising, 45(4), 441-458. doi: 10.1080/00913367.2016.1214649

Royne, M.B., Martinez, J., Oakley, J., \& Fox, A.K. (2012). The effectiveness of benefit type and price endings in green advertising. Journal of Advertising, 41(4), 85-102. doi: 10.1080/00913367.2012.10672459

Ryoo, Y., Hyun, N.K., \& Sung, Y. (2017). The Effect of Descriptive Norms and Construal Level on Consumers' Sustainable Behaviors. Journal of Advertising. 46(4), 536549. doi: 10.1080/00913367.2017.1396514

Sahin, S., Baloglu, S. \& Topcuoglu, E. (2019). The Influence of Green Message Types on Advertising Effectiveness for Luxury and Budget Hotel Segments. Cornell Hospitality Quarterly. 61(4), 1-18, doi: 10.1177/1938965519892189

Schmuck, D., Matthes, J., \& Naderer, B. (2018). Misleading Consumers with Green Advertising? An Affect-Reason-Involvement Account of Greenwashing Effects in Environmental Advertising. Journal of Advertising. 47(2), 127-145, doi: 10.1080/00913367.2018.1452652

Schuhwerk, M.E., \& Lefkoff-Hagius, R. (1995). Green or non-green? Does type of appeal matter when advertising a green product? Journal of Advertising. 24(2), 45-54.

Segev, S., Fernandes, J., \& Hong, C. (2016). Is your product really green? A content analysis to reassess green advertising. Journal of Advertising, 45(1), 85-93, doi: $10.1080 / 00913367.2015 .1083918$

Sheehan, K. and Atkinson, L. (2012). Special issue on green advertising: Revisiting green advertising and the reluctant consumer. Journal of Advertising, 41(4), 5-7.

Shin, S., Ki, E-J., \& Griffin, W.G. (2017). The effectiveness of fear appeals in 'green' advertising: An analysis of creative, consumer, and source variables. Journal of

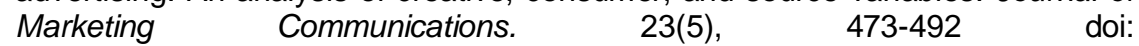
10.1080/13527266.2017.1290671

Shrum, L.J., McCarty, J.A. \& Lowrey, T.M. (1995) Buyer characteristics of the green consumer and their implications for advertising strategy. Journal of Advertising, 24(2), 71-84.

Taylor, C.R. (2014). Corporate social responsibility and advertising. International Journal of Advertising 33 (1),11-15, doi: 10.2501/IJA-33-1-011-015

Thøgersen, J. (2002). Promoting Green Consumer Behavior with Eco- Labels. In T. Dietz \& P.C. Stern (Eds.), New tools for environmental protection: Education information and voluntary measures (pp.83-104). Washington, DC: National Academy Press. 
Thøgersen, J., Jørgensen, A., \& Sandager, S. (2012). Consumer Decision Making Regarding a "Green" Everyday Product. Psychology and Marketing, 29(4), 187197. doi:10.1002/mar.20514

Tiwari, S., Tripathi, D. M., Srivastava, U., \& Yadav, P. K. (2011). Green Marketing Emerging Dimensions. Journal of Business Excellence, 2(1), 18-23.

Tucker, E.M., Rifon, N.J., Lee, E.M., \& Reece, B.B. (2012). Consumer receptivity to green ads: A test of green claim types and the role of individual consumer characteristics for green ad response. Journal of Advertising, 41(4), 9-23. doi:10.1080/00913367.2012.10672454

Usrey, B., Palihawadana, D., Saridakis, C., \& Theotokis, A. (2020). How Downplaying Product Greenness Affects Performance Evaluations: Examining the Effects of Implicit and Explicit Green Signals in Advertising. Journal of Advertising. 49, 125140, doi: $10.1080 / 00913367.2020 .1712274$

Wells, V. K. (2012). Foraging: An ecology model of consumer behaviour? Marketing Theory, 12(2), 117-136. doi.org/10.1177/1470593112441562

White, K., MacDonnell, R., \& Dahl, D.W. (2011). It's the mind-set that matters: The role of construal level and framing in influencing consumer conservation behaviors. Journal of Marketing Research, 48(3), 472-485. doi:10.1509/jmkr.48.3.472

Xie, G-X., \& Kronrod, A. (2012). IS THE DEVIL IN THE DETAILS? The Signaling Effect of Numerical Precision in Environmental Advertising Claims. Journal of Advertising, 41(4), 103-117, doi: 10.2753/JOA0091-3367410407

Yazdanifard, R., \& Mercy, I.E. (2011, January). The impact of Green Marketing on Customer satisfaction and Environmental safety. Paper presented at International Conference on Computer Communication and Management, Sydney, Australia.

Yoon, S., Kim, Y., \& Baek, T.H. (2016). Effort investment in persuasiveness: a comparative study of environmental advertising in the United States and Korea. International Journal of Advertising, 35(1), 93-105, doi: 10.1080/02650487.2015.1061963

Zinkhan, G.M. \& Carlson, L. (1995). Green advertising and the reluctant consumer. Joumal of Advertising, 24(2), 1-5. 